\title{
The Culture of Excellent Public Service in Public Hospital, Kajen District, Pekalongan Regency to Improve Public Satisfaction
}

\author{
Nina Widowati \\ \{ninawidowati.fisip@gmail.com\} \\ Universitas Diponegoro, Indonesia
}

\begin{abstract}
Humans and cultures develop side by side in all aspects of life, as well as in public services. The culture of public service provides a positive direction to achieve the satisfaction of the people served. The purpose of this study is to look at the culture of public services that are developing at public hospital, in Kajen district, Pekalongan Regency. During this time, public services are still a problem that must be resolved, because the services carried out still get a lot of complaints from the public. Long queues, long waiting times, and inadequate infrastructure are problems that need attention. The design of this research is descriptive qualitative. The results showed that the public hospital in Kajen district, Pekalongan Regency had built a culture of good public service, one of which was to provide special counters for the elderly and people with special needs. They don't need to queue. It is expected that the hospital can maintain a good service culture, as well as improve infrastructure and human resources in health services for the surrounding community.
\end{abstract}

Keywords: Service Culture, Professionalism, Community Satisfaction.

\section{Introduction}

Public services are a strategic point in building good governance in Indonesia. Public services that satisfy the community will be able to generate public trust and support. To generate public trust and support, this kind of service must be continuously carried out. So far, the quality of public services is still considered not meet the expectations of the community. In fact, there are still many complaints from the community, both through the suggestion box and through the mass media. It means that quality services have not satisfied the community yet.

Hospital in Kajen sub-district, hereinafter referred as Kajen hospital is one of the regional hospitals in Pekalongan Regency which implement public health service efforts with the mission: "hospital with excellent quality service and safe-life patient oriented". So far, Kajen Hospital has been trying to provide good services to the community, but there are still complaints relating to the services, such as a long queue for taking service numbers as the consequences of the limited number of doctors. Patients should come to the hospital early in the morning at $5 \mathrm{a} . \mathrm{m}$. to get the queue number (radarsemarang.com), and some patients come earlier (at 4 a.m.) to get an early queue of services. Every morning, there are almost 300 to 350 patients who come to the hospital. The long queue creates inconvenience for people who want to get health services. 
Kajen hospital has tried to solve the problems in terms of health services. In institution level, public services should fulfill to the same service pattern, where the rights and obligations of service providers and recipients must be clear and known by each party. Kajen hospital created service culture to minimize the long queue problems, namely by opening of special counters for the elderly and counters for patients with special needs. They get priority services and do not need to queue. The main purpose of service culture is to fulfill the satisfaction of the patient in getting health services.

\section{Literature Review}

Service means serving a service needed by the community in all fields [1]. Lewis and Gilman in Hayat [2] assert that public service is public trust. Public services are carried out in accordance with existing rules and regulations. The mandate of Law Number 25, 2009 [3] becomes a reference for the administration of the state to provide optimal and maximum services. Rochman [4] states that services are all activities to fulfill the basic needs and the rights of every citizen.

A good and excellent public service is how to facilitate all the processes of activities meet the needs of the community. Nisjar in Sedarmayanti [1] explains good services include:

a) Having service procedures that must be easy to understand and implement, avoiding bureaucratic procedures that are very excessive and convoluted;

b) Providing clarity and certainty for customers;

c) Being effective and efficient;

d) Paying attention to speed and timeliness;

e) Making customers easily in accessing information relating to services at any time;

f) Treating customers services as the main priority with the motto "customer is a king who is always right".

The services provided must be able to create a harmonious relationship between service providers and the community. Fast, precise, accurate services must be provided to the community, so that people get satisfaction [5]. To create community satisfaction needs to be supported by a good service culture. Culture is formed from the collection of attitudes of each member of an institution. The culture in the organization is as much as the number of members of the organization Tampubolon in Sembiring [6]. Ueno (2012) as quoted by Robiansyah [7] explains that there are several reasons that make service culture an important factor. First, a strong culture of service will drive employee behavior consistently in serving customers. Second, service culture is a prerequisite for success in building a customer-oriented organization. Third, management is unable to oversee all employees. Service culture is expected to be able to influence the accuracy of employee behavior in service, so it is not wrong if Ostrom states that one of the priorities in the study of service is how to create and maintain a service culture. Characteristics of organizational culture include: first is professionalism, which is accountable, transparency, discipline, effective, efficient, continuous quality improvement, and visionary; the second is community-oriented, which includes responses to complaints, aspirations, participation, and appreciation; and third is performanceoriented consisting of SOPs, work teams, evaluation and reporting on the performance of public sector organizations [6]. 


\section{Research Methods}

This research was conducted at the regional general hospital in Kajen Subdistrict, on Karangrasi Road, Karanganyar, Pekalongan Regency, Central Java. The design of this study is a qualitative descriptive study, which describes the service culture in Kajen Hospital, Pekalongan Regency. Informants are 12 patients who use outpatient services and 14 officers both medical (8) and administrative (6).

\section{Results and Discussion}

The service culture phenomenon that became the focus of the study was 3 aspects, namely professionalism, service oriented to the community, and service oriented to performance. From the research in the field, the following results were obtained:

\subsection{Professionalism}

Professionalism is the competence to carry out duties and functions properly and correctly, as well as the commitment of its members to improve their abilities. At the Kajen hospital, professionalism is already looking good. This is evidenced by the accuracy of the officers in providing services to patients. In dealing with patients, it has been done in accordance with existing procedures. For patients who are elderly and those with special needs are prioritized in line service, namely by opening their own counters. To treat general patients, the same is done, namely by taking a queue number to the available counters. Starting January 15, 2019, the Kajen Hospital will make it easy for participants who obtain Social Health Insurance to get online services. In addition, patients who have been examined at Kajen hospital can also take advantage of registering through WhatsApp (WA). Registration time starts at $07.00-12.00$ WIB to register for the next visit.

\subsection{Community-Oriented Services}

In providing services, the Kajen hospital prioritizes community support, by establishing good communication with the community, responding to complaints, respecting the elderly and those with special needs. From the results of the study at the Kajen hospital, the relationship between hospital employees in dealing with patients was good. This makes the patient feel comfortable. Besides communication goes both ways, it is proven that the public is free to ask. For those who feel unsatisfied, Kajen Hospital provides a complaint box containing a coin that is inserted in the box. The number of coins indicates there is dissatisfaction in service. If the box looks empty, it means the service is what you want it to be. Kajen Hospital also accepts free Class III patients just by showing their identity card. This is excluding patients who have Health Social Insurance, Healthy Kajen Card, and General Insurance.

The management of the Kajen hospital also launched LAZIS (the Alms and charity institute) which functions to help patients who cannot afford, do not have health insurance, regional health insurance, or other health guarantees. Funds were collected from employees of the Kajen Hospital, Pekalongan Regency. 


\subsection{Performance-Oriented Services}

Performance-oriented services can be measured by the availability of standard operating procedures, teamwork, evaluation, and reporting of organizational performance to the public. Kajen Hospital has a standard operating procedure, which is a document relating to procedures that are applied chronologically to complete a job aimed at obtaining effective and efficient work. The task of the Kajen Hospital is to carry out health efforts by prioritizing healing (curative), rehabilitation (rehabilitative), efforts to increase (promotive), prevention of disease (preventive) and carry out quality referral efforts and services according to the standard operating procedure of the hospital service. For poor people who need dialysis, Kajen Hospital prepares a free pick-up, and the funding will use funds of LAZIS (Lembaga Amal, Zakat, Infak, dan Shodakoh), a Zakat, infaq and alms institutions, managed by Rumah Zakat Indonesia. Kajen hospital has also received five stars of plenary accreditation. This shows that Kajen Hospital has a high performance.

\section{Conclusion}

From the results of a field study on a superior public service culture at Kajen Hospital, Pekalongan Regency in an effort to increase community satisfaction can be concluded as follows:

a) The culture of public services at Kajen Hospital has been going well. This is evidenced by the existence of professionalism in service to the community. Kajen Hospital gives priority to the elderly and people with special needs in providing health services.

b) Community-oriented services are also considered good. This is evidenced by the existence of LAZIS that serves to help patients who are economically disadvantaged, outside the BPJS health, regional health insurance, or other health insurance.

c) Performance-oriented services have also shown positive things. This is proven by the achievement of Five Stars of Plenary Accreditation for Kajen Hospital. In addition, hospital staffs provide free pickup for the poor who will dialysis.

\section{References}

[1] Sedarmayanti, "Public Administration Reform, Bureaucracy Reform, and Future Leadership," 2010.

[2] Hayat, "Management of Public Services," 2017.

[3] "Undang-Undang No 25 Tahun 2009 tentang Pelayanan Publik.".

[4] A. A. Rohman, "Public Service Reform," 2010.

[5] W. M. Zaenal Mukarom, "Building Public Service Work," 2016.

[6] S. Masana, "Culture of Organizational Performance (Government Organization perspective,)," 2012.

[7] R. I, "Economic Forum,” J. Econ. Manag. Account., vol. 19, no. 2, 2017. 